\title{
Biological Performance of Wood Modified with Orthophthalic Polyester Resin and Styrene
}

\author{
Saip Nami KARTAL ${ }^{1}$, Ömer KANTOĞLU ${ }^{2}$ Ö \\ ${ }^{1}$ Istanbul University-Cerrahpasa, Faculty of Forestry, Istanbul, TURKEY \\ ${ }^{2}$ Turkish Atomic Energy Authority (TAEK), Ankara, TURKEY \\ *Corresponding Author: snkartal@istanbul.edu.tr
}

Received Date: 08.10.2019

Accepted Date: 23.03 .2020

\section{Abstract}

Aim of study: This study evaluated the improvements in dimensional stability and biological resistance of wood against fungal degradation, and termites by radiation-induced in situ copolymerization of three types of low viscosity-unsaturated polyester resin with styrene.

Material and methods: Radiation polymerization of unsaturated polyester resin with styrene in a viscous system was performed at ambient temperature using gamma $(\gamma)$-rays. In the study, water absorption and dimensional stability of the modified wood specimens were first determined. The wood specimens were also tested against decay and mold fungi and termites in laboratory.

Main results: Results after 24-h water immersion of modified wood specimens showed that more than $70 \%$ of water repellent effectiveness was obtained in the wood specimens after modifications with the three formulations of tested chemical mixtures; however, the highest anti-swell efficiency values were observed in the specimens treated with the only one type of treating mixtures. Mold resistance tests showed that the treating mixtures tested were not completely inhibited mold growth; however, some improvements in mold scores were seen when compared to control wood specimens. Results showed that after modifications, the specimens showed increased resistance against the fungi and termites considering untreated control specimens.

Highlights: Modifications by styrene and UP resin with different formulations and gamma irradiation greatly improved water absorption and volumetric swell of test specimens in comparison with unmodified control specimens.

Keywords: Irradiation, Polymerization, Unsaturated polyester, Styrene, Wood, Decay, Termite

\section{Ortoftalik Poliester Reçinesi ve Stiren ile Modifiye Edilmiş Odunun}

\section{Biyolojik Performansı}

\section{$\ddot{\mathbf{O} z}$}

Çalışmanın amacı: $\mathrm{Bu}$ çalışmada, üç tip düşük viskoziteli doymamış polyester reçinenin stiren ile radyasyonla yerinde indüklenerek kopolimerizasyon sonucu ahşabın çürüklük ve küf mantarlarına karşı performansı ve boyutsal özelliklerindeki iyileşmeler incelenmiştir.

Materyal ve yöntem: Ortoftalik doymamış polyester reçinenin viskoz sistemde stiren ile radyasyon yoluyla polimerizasyonu oda sıcaklığında gamma $(\gamma)$ ışınları kullanılarak yapılmıştır. Çalışmada, modifiye edilmiş odun örneklerinin su alma ve boyutsal stabilitesi belirlenmiş̧ir. Örnekler ayrıca laboratuvar ortamında çürüme, küflenme ve termit dayanımı testlerine tabi tutulmuştur.

Sonuçlar: Modifiye edilmiş ahşap numunelerin 24 saatlik suya batırılmasından sonraki sonuçlar, test edilen kimyasal karışımların üç formülasyonu ile modifikasyonlar yapıldıktan sonra, ahşap numunelerde su itici etkinliğinin\% 70'inden fazlasının elde edildiğini göstermiştir; bununla birlikte, en yüksek şişme karşıtı verimlilik değerleri, sadece bir tür muamele karışımının uygulandığı numunelerde görülmüştür. Küflenmeye karş1 dayanıklılık testleri, test edilen muamele karışımlarının küf oluşumunu tamamen önlemediğini göstermiştir; Bununla birlikte, kontrol örnekleri ile karşılaştırıldığında küflenme derecelerinde bazı iyileşmeler görülmüştür.

Araştırma vurguları: Modifikasyonlardan sonra yapılan çürüme ve termit dayanıklılık testleri, kontrol numuneleri göz önüne alındığında, mantar ve termitlere karşı dayanıklılı̆̆ın arttığını ortaya koymuştur.

Anahtar Kelimeler: Işıma, Polimerizasyon, Doymamış polyester, Stiren, Odun, Çürüme, Termit

Citation (Atıf): Kartal, S. N. \& Kantoglu, O. (2020). Biological Performance of Wood Modified with Orthophthalic Polyester Resin and Styrene. Kastamonu University Journal of Forestry Faculty, 20 (2), 97-106.
97 This work is licensed under a Creative Commons Attribution-NonCommercial 4.0 International License.

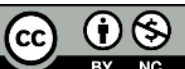




\section{Introduction}

Modification is aimed to improve many properties of wood material principally related to its hygroscopicity, dimensional stability, biological performance against fungi and insects. Wood modification processes are currently facing major developments. Thus, several novel technologies and modifying agents such as thermal modification, acetylation, furfurylation, and various impregnation and polymerization processes as well as new monomer and polymer systems, and resins have been successfully introduced in the market (Sandberg et al., 2017).

In lumen modifications where wood is first vacuum-impregnated with liquid monomers, then in situ polymerized, and the polymer is finally located almost solely in the lumens of the wood, unsaturated polyester (UP) resins are most often used in combination with other monomers, making them less expensive and improving their properties. Many polyester resins are available as commercial products in wood modification processes. Polyester and styrene are polymerized individually and in combinations by gamma $(\gamma)$-radiation or benzoyl peroxide; however, mixing styrene with polyester decreases viscosity and, in turn, increases penetration of resin system into the wood (Ibach \& Rowell 2013). Jurkin \& Pucic (2006) have stated that UP resins are most commonly used thermosetting resins and are being increasingly applied for several purposes due to their balanced mechanical and chemical properties and a low cost (Aziz et al., 2005).

UP resins are the condensation products of unsaturated acids or anhydrides and diols with/without diacids and the unsaturation part provides a site for cross-linking. Basically, UP resins comprise polyester coils swollen to some extent in a vinyl monomer as a solvent and crosslinking agent and are being used as the polymer matrix (Dholakiya, 2012). Cao and Lee (2003) have discussed that UP resins are commonly used in the composite industry, provide notable mechanical and chemical properties and increase resistance to chemicals and weathering. The cross-linking reaction between UP resins and vinyl monomers, i.e. styrene, allows one polymer series to join with other polymer series, and to yield a three dimensional network. These reactions finally convert the whole resin system to a hard, thermoset solid.

The crosslinking reaction of UP resins is mostly initiated by different curing methods such as thermal or redox initiator even though there are a number of concerns in such methods i.e. incomplete conversion, difficulties of homogeneous mixing with UP resin, release of residual styrene and undesirable odor. The alternative way of curing UP resins is thus radiation technology with many advantages over the conventional curing methods. In radiation techniques, where no further catalyst or additives are needed, entire curing process can be completed at low temperatures (Jurkin \& Pucic 2006). Gamma irradiation is one of the most used radiation techniques in wood modification by monomers. Since wood material contains a mixture of high molecular weight polymers, high-energy radiation depolymerizes these polymers and free radicals are formed to start polymerization (Ibach \& Rowell, 2013).

Numerous sorts of UP resins with styrene have been effectively used for wood protection and consolidation since the volatilization of the polymer mixture is notably decreased from the matrix (Mahmoud et al., 2001). The objective of the study was to improve dimensional stability, water absorption, decay and termite resistance of Scots pine wood by impregnating with UP resin and styrene under gamma irradiation process. This paper represents preliminary test results that are part of a larger research project carried out with the cooperation of Turkish Atomic Energy Authority (TAEK). The project principally focuses on application of radiation techniques for protecting cultural heritage and property such as wood, paper, textiles etc. The application of ionizing radiation for the disinfection of cultural heritage artifacts has been successfully demonstrated in recent years. The project deals with assessing the effect of irradiation on the functional characteristics of such artifacts' base materials and minor 
constituents, as well as on irradiation effects and suitable irradiation processes for larger use of the method. In the project, several consolidation processes are also applied to cultural heritages by radiation processing.

\section{Material and Methods}

\section{Wood Specimens}

Test specimens were prepared from sapwood of a Scots pine log (Pinus sylvestris L.) obtained from Artvin, Turkey. The specimens were cut from planed strips on which the growth rings ran in any direction except entirely tangential on the wide faces. The longitudinal faces were parallel to the direction of the grain. Transverse cuts were prepared neatly to produce sharp edges. The specimens did not include any cracks, decay, stain, insect damage or other defects based on the EN 113 and EN 84 standard test methods (EN 1997a,b). Test specimens were acclimatized in a conditioning room at $20 \pm 2$ ${ }^{\circ} \mathrm{C}$ and $65 \pm 5 \%$ relative humidity (RH) for 30 days before treatment.

\section{Treatments}

Styrene and orthophthalic unsaturated polyester (UP) resin were obtained from Toteks Dış. Tic. Tekstil San. Ltd. Şti. UniGrup, Istanbul, Turkey. Styrene is a colorless, combustible liquid and soluble in ethanol and insoluble in water. Styrene is commonly used in mixtures with other polymerizable substances such as unsaturated polyester resins for the consolidation of wood. UP resins are colorless to pale yellowish, viscous liquids and used usually with irradiation curing for the consolidation purposes (Unger et al., 2001).

Test specimens were weighed, and then vacuum-treated (the specimens were submerged in the treating solution then exposed to 30 minutes vacuum for approx. 500 $\mathrm{mm} \mathrm{Hg}$ followed by a 30 minute period at atmospheric pressure) with the UP resin and styrene mixtures based on the EN 113 standard test method (EN 1997a).

The used mixtures by weight (w/w) were as follows:
MIX A: $48 \%$ styrene + $52 \%$ UP resin T1

MIX B: $48 \%$ styrene $+52 \%$ UP resin T1 UV

MIX C: $48 \%$ styrene $+52 \%$ UP resin T3

In these formulations, $\mathrm{T} 1$ and $\mathrm{T} 3$ are the codes given by the manufacturer company and UV means ultraviolet ray protective compound. MIX represents mixtures of resin and styrene compounds.

Since a patent application for the modification procedures followed in the study has been filed, no more details are available for mixtures of the modifying agents due to the pending patent.

After treatments, the wood specimens were dry-blotted and re-weighed to calculate preservative uptake as $\mathrm{kg} / \mathrm{m}^{3}$. Retention levels of the resin mixtures and weight gain were calculated by specimen weights after the treatments.

The treated specimens were then immediately exposed to gamma irradiation process. In the processes done at TAEK, Ankara, Turkey, the specimens were irradiated to $25 \mathrm{kGy}$ dose by using Isotope Ob-Servo Sanguis $\mathrm{Co}^{60}$ gamma irradiator at a fixed dose rate of $1.714 \mathrm{kGy} / \mathrm{h}$ at room temperature and atmosphere. The specimens were then dried again at $60 \pm 2{ }^{\circ} \mathrm{C}$ for 72 hours.

Water Absorption, Volumetric Swell, Water Repellent Effectiveness and Anti-Swell Efficiency of Modified and Gamma Irradiated Wood Specimens

Water absorption (WA) was calculated based on the below equation (Eq. 1):

WA $(\%)=\left(\left(\mathrm{W}_{2}-\mathrm{W}_{1}\right) \quad / \quad \mathrm{W}_{1}\right) \quad \mathrm{x} \quad 100$ (1)

where $\mathrm{W}_{2}$ is the weight of wood specimen (15 (T) $x 25(\mathrm{R}) \times 50 \mathrm{~mm}(\mathrm{~L})$ ) after absorption in water for either 2 or $24 \mathrm{~h}(\mathrm{~g})$, and $\mathrm{W}_{1}$ is the oven-dried (at $103^{\circ} \mathrm{C}$ ) weight of wood specimen before absorption in water $(\mathrm{g})$.

Volumetric swelling (VS) was calculated by evaluating the oven-dried (at $103^{\circ} \mathrm{C}$ ) and wet dimensions of the wood specimens based on the below equation (Eq. 2): 
$\operatorname{VS}(\%)=\left(\left(\mathrm{V}_{1}-\mathrm{V}_{0}\right) / \mathrm{V}_{0}\right) \times 100$

where $V_{1}$ is the wet volume of wood specimen after absorption in water for either 24 or $48 \mathrm{~h}$ $\left(\mathrm{mm}^{3}\right)$, and $\mathrm{V}_{0}$ is the oven- dried (at $103^{\circ} \mathrm{C}$ ) volume of wood specimen $\left(\mathrm{mm}^{3}\right)$.

Water repellent effectiveness was found according to the water absorption values of the wood specimens as follows (Eq. 3):

$\operatorname{WRE}(\%)=100 \times\left(\mathrm{WA}_{1}-\mathrm{WA}_{2}\right) / \mathrm{WA}_{1}$

where $\mathrm{WA}_{1}$ is water absorption of untreated wood specimens, while $\mathrm{WA}_{2}$ is water absorption of modified wood specimens.

Volumetric swelling coefficient (S) and anti-swell efficiency (ASE) were then calculated according to the volumetric swell values of the specimens as follows (Eqs. 4 and 5):

$\mathrm{S}(\%)=100 \times\left(\mathrm{V}_{2}-\mathrm{V}_{1}\right) / \mathrm{V}_{1}$

where $V_{2}$ is wood volume after humidity conditioning or wetting with water, and $\mathrm{V}_{1}$ is wood volume of oven-dried specimen before conditioning or wetting.

$\operatorname{ASE}(\%)=100 \times\left(\mathrm{ASE}_{1}-\mathrm{ASE}_{2}\right) / \mathrm{ASE}_{1}$

where $\mathrm{ASE}_{1}$ is anti swell value of untreated control specimens while $\mathrm{ASE}_{2}$ is anti swell value of modified wood specimens.

\section{Fungal Decay Resistance of Modified and} Gamma Irradiated Specimens

Decay tests were achieved based on the Kolle flasks test method based on the EN 113 standard test method (EN 1997a). The specimens $(15(\mathrm{~T})$ x $25(\mathrm{R})$ x $50 \mathrm{~mm}(\mathrm{~L}))$ were first dried at $60 \pm 2{ }^{\circ} \mathrm{C}$. For each treatment group, 12 steam-sterilized wood specimens (15 x 25 x $50 \mathrm{~mm}$ ) were inoculated with Trametes (Coriolus) versicolor (MAD 697) and Fomitopsis (Tyromyces) palustris (TYP 6137) fungi. After 12 weeks of incubation in a conditioning room at $20 \pm 2{ }^{\circ} \mathrm{C}$ and $65 \pm 5 \%$ $\mathrm{RH}$, mycelium was taken off from the specimens before the specimens were dried at
$60 \pm 2^{\circ} \mathrm{C}$ to constant weight. Then, weight losses in the wood specimens were analyzed according to the original constant weights.

\section{Mold Resistance of Modified and Gamma Irradiated Specimens}

Modified and untreated control specimens $(7 \mathrm{~mm}(\mathrm{~T})$ x $20 \mathrm{~mm}(\mathrm{R})$ x $70 \mathrm{~mm}(\mathrm{~L})$ ) were examined for resistance to mold fungi based on a modification of the ASTM D4445 standard test method (ASTM 2012). Three mold fungi, Aspergillus niger ASN 6275, Trichoderma harzianum Rifai FS19 and Penicillium fellutanum F66 were cultivated and retained on $2 \%$ malt agar at $27 \pm 2{ }^{\circ} \mathrm{C}$, and $80 \pm 5 \% \mathrm{RH}$. A spore suspension from the three test fungi were made by washing the surface of individual 2-week-old Petri plate cultures with sterile distilled water (DW) $(10-15 \mathrm{~mL}$ ). Washings were then merged in a spray bottle and diluted to nearly $100 \mathrm{~mL}$ with DW to yield nearly $3 \times 10^{7}$ spores $/ \mathrm{mL}$. The spray bottle was regulated to deliver 1-mL inoculum per spray. Specimens previously sterilized with steam were sprayed with $1 \mathrm{~mL}$ of the suspension and incubated at $27 \pm 2{ }^{\circ} \mathrm{C}$ and $80 \pm 5 \% \mathrm{RH}$ for 4 weeks. After incubation, test specimens were visually evaluated using a scale of $0-5$, with 0 showing the specimen was completely free of mold growth, and 5 that it was entirely covered with mold.

\section{Termite Resistance of Modified and Gamma Irradiated Specimens}

Modified and untreated specimens $(20 \mathrm{~mm}$ (T) x $20 \mathrm{~mm}(\mathrm{R}) \times 10(\mathrm{~L}) \mathrm{mm}$ ) were subjected to the subterranean termites, Coptotermes formosanus based on the Japan Industrial Standard (JIS K 2004). Details are available in the respective standard. The weight losses of the specimens after 3-week-termite attack were calculated according to the differences in the initial and final oven-dry (at $103^{\circ} \mathrm{C}$ ) weights of the specimens. Termite mortality was also found after the 3-week-exposure.

\section{Results and Discussion}

Uptake of the treating solution mixtures by wood specimens after modifications is given in 
Table 1. The table also represents weight gain of the specimens after modifications. The uptake values of modified specimens much lower than that of DW-treated control wood specimens $\left(723 \mathrm{~kg} / \mathrm{m}^{3}\right)$. This suggested that the high viscosity (about 200-400 centipoises (cPs) and molecular size of the compounds for modifications played an important role in obtaining less retention levels when compared to

DW.

Table 1: Uptake and weight gain in the specimens after modifications

\begin{tabular}{lcc}
\hline \multicolumn{1}{c}{$\begin{array}{c}\text { Specimens/ } \\
\text { Treatments }\end{array}$} & $\begin{array}{c}\text { Uptake of modification } \\
\text { compounds }\left(\mathrm{kg} / \mathrm{m}^{3}\right)^{*}\end{array}$ & $\begin{array}{c}\text { Weight gain after chemical } \\
\text { modification }(\%) *\end{array}$ \\
\hline $\begin{array}{l}\text { Modified and gamma irradiated wood } \\
\text { specimens - MIX A } \\
(48 \% \text { styrene + 52\% UP resin T1) }\end{array}$ & $454.0(46.5)$ & $87.4(15.1)$ \\
\hline $\begin{array}{l}\text { Modified and gamma irradiated wood } \\
\text { specimens - MIX B } \\
(48 \% \text { styrene + 52\% UP resin T1 UV) }\end{array}$ & $442.0(59.0)$ & $82.4(15.4)$ \\
\hline $\begin{array}{l}\text { Modified and gamma irradiated wood } \\
\text { specimens - MIX C } \\
(48 \% \text { styrene + 52\% UP) }\end{array}$ & $402.0(88.1)$ & $72.1(13.8)$ \\
*Each number is average of 120 specimens. Values in the parentheses are standard deviations. Uptake of DW in \\
unmodified control specimens was $723.0( \pm 67.2) \mathrm{kg} / \mathrm{m}^{3}$.
\end{tabular}

Table 2 shows water absorption and volumetric swell values of control and modified wood specimens as well as the effect of the modifying agents and gamma irradiation on water repellent effectiveness and anti swell efficiency. The values were obtained from the specimens immersed in DW for 24 and $48 \mathrm{~h}$. Results revealed that water absorption and volumetric swell were greatly improved in modified and gamma irradiated specimens when compared to control specimens. Interestingly, gamma irradiation in untreated wood specimens (without the resin and styrene) resulted in considerably less water absorption (around $52 \%$ for $24 \mathrm{~h}$ immersion; $45 \%$ for $48 \mathrm{~h}$ immersion) in comparison with untreated specimens without gamma irradiation. However, volumetric swell values in gamma irradiated control specimen were higher than those in control specimens without gamma irradiation (around 25\% for $24 \mathrm{~h}$ immersion; $18 \%$ for $48 \mathrm{~h}$ immersion). The best results among the modified and gamma irradiated specimens were obtained in the specimens treated with $48 \%$ styrene $+52 \%$ UP resin T3 formulation. In these treatments, water repellent effectiveness was nearly $78 \%$; while anti swell efficiency was $66 \%$ when compared to untreated and non-radiated specimens for 24 $\mathrm{h}$ immersion. These results suggest that gamma irradiation may have caused some chemical changes in particularly in the hemicelluloses and cellulose components of wood that are responsible for water absorption.

The most of the available $\mathrm{OH}$ groups of the cell wall are related with the hemicelluloses of wood cell. Hill (2006) states that the $\mathrm{OH}$ groups are very vital in defining many wood properties. Many wood properties are dependent on the occurrence of such groups and, particularly, hydrogen-bonding interactions between the molecular components of the cell wall. Furthermore, the $\mathrm{OH}$ groups are also responsible for water absorption causing dimensional instability. Despot et al. (2012) reviewed that the break down of cellulose component in wood after gamma irradiation is very normal and holocellulose in the cell walls is destroyed by gamma irradiation. Even minor doses of gamma radiation result in a degradation of hemicelluloses' pentose forming different compounds and new chemical bonds (Seifert, 1964). The dose of $500 \mathrm{kGy}$ results in increased wood solubility due to depolymerization and destruction of 
hemicelluloses (Chawla, 1985). Borysiak (2010) investigated that the substance of wood cellulose was alike during the early stage of gamma radiation at the dose range 20-300 $\mathrm{kGy}$; but, when the doses increased above the level of $500 \mathrm{kGy}$ then the cellulose content diminished quickly. The highest irradiation dose (9 MGy) resulted in the total destruction of wood. Katsumata et al. (2007a, b) showed a decrease on the degree of polymerization of cellulose by accelerating the dose up to 100 kGy in Cryptomeria japonica wood. The decrease in water absorption and volumetric swell in modified specimens is because the hydrophobic polystyrene protects the wood surfaces and remains in the cell wall and lumen, causing less water penetration into the wood (Cao \& Lee, 2003). There was a noteworthy enhancement of water repellence between the untreated and treated wood. Different wood species treated with a polymer mixture containing a macro-monomer and styrene had enhanced water repellency, compression and bending strength (Baki et al., 1993). Mahmood et al. (2001) showed that the use of the unsaturated polyester/styrene mixtures resulted in a higher water repellent effectiveness, and anti-swelling efficiency. Devi et al. (2003) also found that chemical modification by styrene and methacrylate improved the volumetric swelling and antishrink efficiency in rubber wood.

Table 2: Dimensional stability and water absorbance test results

\begin{tabular}{|c|c|c|c|c|c|}
\hline Specimens / Treatments & $\begin{array}{l}\text { Immersion } \\
\text { duration }\end{array}$ & $\begin{array}{l}\text { Water } \\
\text { absorption } \\
\text { (WA) }(\%)^{*}\end{array}$ & $\begin{array}{l}\text { Volumetric } \\
\text { swell } \\
\text { (VS) }(\%)^{*}\end{array}$ & $\begin{array}{l}\text { Water repellent } \\
\text { effectiveness } \\
\text { based on water } \\
\text { absorption } \\
\text { WRE }(\%)^{*}\end{array}$ & $\begin{array}{c}\text { Anti swell } \\
\text { efficiency } \\
\text { based on } \\
\text { volumetric swell } \\
\text { (ASE) }(\%)^{*}\end{array}$ \\
\hline $\begin{array}{l}\text { Modified and gamma } \\
\text { irradiated wood specimens } \\
\text { - MIX A ( } 48 \% \text { styrene + } \\
52 \% \text { UP resin T1) }\end{array}$ & $24 \mathrm{~h}$ & $\begin{array}{l}21.56 \\
(2.11) \mathrm{C}\end{array}$ & $\begin{array}{c}9.47 \\
(3.22) \mathrm{AB}\end{array}$ & $\begin{array}{c}74.46 \\
(12.09) \mathrm{A}\end{array}$ & $\begin{array}{l}13.93 \\
(2.65) \mathrm{C}\end{array}$ \\
\hline $\begin{array}{l}\text { Modified and gamma } \\
\text { irradiated wood specimens } \\
\text { - MIX B (48\% styrene + } \\
52 \% \text { UP resin T1 UV) }\end{array}$ & $24 \mathrm{~h}$ & $\begin{array}{l}19.18 \\
(3.04) \mathrm{C}\end{array}$ & $\begin{array}{c}6.92 \\
(2.00) \mathrm{B}\end{array}$ & $\begin{array}{c}77.28 \\
(13.45) \mathrm{A}\end{array}$ & $\begin{array}{l}37.16 \\
(7.45) \mathrm{B}\end{array}$ \\
\hline $\begin{array}{l}\text { Modified and gamma } \\
\text { irradiated wood specimens } \\
\text { - MIX C (48\% styrene + } \\
52 \% \text { UP resin T3) }\end{array}$ & $24 \mathrm{~h}$ & $\begin{array}{c}18.90 \\
(2.90) \mathrm{C}\end{array}$ & $\begin{array}{l}3.70 \\
(1.45) \mathrm{C}\end{array}$ & $\begin{array}{c}77.61 \\
(11.10) \mathrm{A}\end{array}$ & $\begin{array}{c}66.36 \\
(5.89) \mathrm{A}\end{array}$ \\
\hline $\begin{array}{l}\text { Gamma irradiated } \\
\text { unmodified control } \\
\text { specimens }\end{array}$ & $24 \mathrm{~h}$ & $\begin{array}{l}40.75 \\
(9.34) \mathrm{B}\end{array}$ & $\begin{array}{c}13.80 \\
(3.33) \mathrm{A}\end{array}$ & - & - \\
\hline $\begin{array}{l}\text { Untreated control } \\
\text { specimens }\end{array}$ & $24 \mathrm{~h}$ & $\begin{array}{c}84.41 \\
(11.43) \mathrm{A} \\
\end{array}$ & $\begin{array}{c}11.01 \\
(2.09) \mathrm{A} \\
\end{array}$ & - & - \\
\hline $\begin{array}{l}\text { Modified and gamma } \\
\text { irradiated wood specimens } \\
\text { - MIX A ( } 48 \% \text { styrene + } \\
52 \% \text { UP resin T1) }\end{array}$ & $48 \mathrm{~h}$ & $\begin{array}{l}29.99 \\
(3.45) \mathrm{C}\end{array}$ & $\begin{array}{c}10.79 \\
(3.02) \mathrm{A}\end{array}$ & $\begin{array}{l}66.15 \\
(8.88) \mathrm{A}\end{array}$ & $\begin{array}{c}18.21 \\
(3.01) \mathrm{B}\end{array}$ \\
\hline $\begin{array}{l}\text { Modified and gamma } \\
\text { irradiated wood specimens } \\
\text { - MIX B (48\% styrene + } \\
52 \% \text { UP resin T1 UV) }\end{array}$ & $48 \mathrm{~h}$ & $\begin{array}{l}26.85 \\
(7.21) \mathrm{C}\end{array}$ & $\begin{array}{c}11.31 \\
(1.87) \mathrm{A}\end{array}$ & $\begin{array}{c}69.69 \\
(14.32) \mathrm{A}\end{array}$ & $14.22(2.22) \mathrm{BC}$ \\
\hline $\begin{array}{l}\text { Modified and gamma } \\
\text { irradiated wood specimens } \\
\text { - MIX C (48\% styrene + } \\
52 \% \text { UP resin T3) }\end{array}$ & $48 \mathrm{~h}$ & $\begin{array}{c}25.99 \\
(4.44) \mathrm{C}\end{array}$ & $\begin{array}{c}6.96 \\
(0.76) \mathrm{B}\end{array}$ & $\begin{array}{c}70.66 \\
(10.87) \mathrm{A}\end{array}$ & $\begin{array}{c}47.23 \\
(7.43) \mathrm{A}\end{array}$ \\
\hline
\end{tabular}


Table 2 (Continued)

\begin{tabular}{|c|c|c|c|c|c|}
\hline Specimens / Treatments & $\begin{array}{c}\text { Immersion } \\
\text { duration }\end{array}$ & $\begin{array}{c}\text { Water } \\
\text { absorption } \\
(\mathrm{WA})(\%)^{*}\end{array}$ & $\begin{array}{l}\text { Volumetric } \\
\text { swell } \\
(\mathrm{VS})(\%)^{*}\end{array}$ & $\begin{array}{c}\text { Water } \\
\text { repellent } \\
\text { effectiveness } \\
\text { based on water } \\
\text { absorption } \\
\text { WRE }(\%)^{*} \\
\end{array}$ & $\begin{array}{c}\text { Anti swell } \\
\text { efficiency } \\
\text { based on } \\
\text { volumetric } \\
\text { swell (ASE) } \\
(\%)^{*} \\
\end{array}$ \\
\hline $\begin{array}{l}\text { Gamma irradiated } \\
\text { unmodified control } \\
\text { specimens }\end{array}$ & $48 \mathrm{~h}$ & $\begin{array}{c}48.37 \\
(9.43) \mathrm{B}\end{array}$ & $\begin{array}{c}15.57 \\
(4.77) \mathrm{A}\end{array}$ & - & - \\
\hline $\begin{array}{l}\text { Untreated control } \\
\text { specimens }\end{array}$ & $48 \mathrm{~h}$ & $\begin{array}{c}88.59 \\
(11.09) \mathrm{A}\end{array}$ & $\begin{array}{c}13.19 \\
(2.32) \mathrm{A}\end{array}$ & - & - \\
\hline
\end{tabular}

*Each number is average of 15 specimens. Values in the parentheses are standard deviations. The same letters in each column indicate that there is no statistical difference between the specimens according to Duncan's Multiple Range Test $(\mathrm{p} \leq 0.05)$.

Table 3 gives mold scorings in the specimens subjected to mold fungi for 4 weeks. Results suggested that no modifying agents and gamma irradiation resulted in comprehensive inhibition of mold growth on the test specimens even though mold ratings in modified specimens were smaller than those in untreated controls. Irradiation in control specimens caused a slight increase in mold growth.

Table 4 indicates the weight losses occurred in the specimens subjected to fungal resistance tests by the two Basidiomycetes fungi in laboratory conditions. When compared to untreated specimens (no radiation), gamma irradiation resulted in increased weight losses in gamma irradiated control specimens exposed to $T$. versicolor, a white rot fungus. However, slight decrease was observed in these values when $T$. palustris, a brown rot fungus, was employed. No complete inhibition by the modifications and gamma irradiation was observed in the decay resistance tests; however, important decreases in weight losses were seen after the modifications. The lowest weight losses were obtained in the specimens with the Mixture C with T3 type resin. Despot et al. (2012) states that as gamma radiation results in break-up of cellulose to smaller water-soluble chains, and that leads to an opening of additional micro-cracks, in which water molecules can simply enter. As a result, gamma irradiated wood is also more accessible to enzymes of fungi. Unger et al. (2001) discusses that depending on the dosage applied, the gamma irradiation causes formation of radicals and ionization of molecules, thus, chemical bonds are fragmented, cellulose chains become reduced and functional groups are changed in wood. Due to chemical changes in wood after radiation, acceleration of aging can lead to increased susceptibility to biological attack. For increased biological resistance to fungi, filling lumens with polymers is an important issue since polymerization makes the cell walls inaccessible to moisture and decay organisms. On the other hand, the amount of polymer in the cell wall is also crucial factor for decay resistance. Some protection to biodegradation is likely at cell wall polymer contents of $10 \%$ or more (Ibach and Rowell 2013). Sandberg et al. (2017) reviews that modified wood has generally lowered equilibrium moisture content and fungi hardly obtain the moisture required for decay. Such wood also physically blocks the entrance of decay fungi from the micro pores of the cell walls and inhibits the action of specific enzymes (Hill, 2006; Rowell et al., 2009; Rowell, 2016). 
Table 3: Mold ratings after 5-week-exposure to mold fungi

\begin{tabular}{|c|c|}
\hline Specimens / Treatments & Mold rating* \\
\hline Control specimens & $4.5(0.9) \mathrm{B}$ \\
\hline Gamma irradiated unmodified control specimens & $4.8(0.7) \mathrm{A}$ \\
\hline $\begin{array}{l}\text { Modified and gamma irradiated wood specimens - } \\
\text { MIX A ( } 48 \% \text { styrene }+52 \% \text { UP resin T1) }\end{array}$ & $3.0(1.2) \mathrm{C}$ \\
\hline $\begin{array}{l}\text { Modified and gamma irradiated wood specimens - } \\
\text { MIX B (48\% styrene + 52\% UP resin T1 UV) }\end{array}$ & $2.5(1.7) \mathrm{C}$ \\
\hline $\begin{array}{l}\text { Modified and gamma irradiated wood specimens - } \\
\text { MIX C ( } 48 \% \text { styrene + } 52 \% \text { UP) }\end{array}$ & $4.3(1.1) \mathrm{B}$ \\
\hline \multicolumn{2}{|c|}{$\begin{array}{l}\text { *Each number is average of } 15 \text { specimens. Values in the parentheses are standard deviations. On a scale of } 0-5 \text {, } \\
\text { with } 0 \text { indicating the specimen was completely free of mold growth, and } 5 \text { that it was completely covered with } \\
\text { mold growth }(0: \text { no growth, } 1: 20 \%, 2: 40 \%, 3: 60 \%, 4: 80 \% \text {, and } 5: 100 \% \text { coverage with mold fungi). The same } \\
\text { letters in the column indicate that there is no statistical difference between the specimens according to Duncan's } \\
\text { Multiple Range Test ( } \square \leq 0.05 \text { ). }\end{array}$} \\
\hline
\end{tabular}

Table 4: Fungal decay resistance tests results

\begin{tabular}{|c|c|c|}
\hline Specimens / Treatments & $\begin{array}{l}\text { Weight loss }(\%) \\
\text { by T.palustris* }\end{array}$ & $\begin{array}{l}\text { Weight loss }(\%) \\
\text { by T. versicolor* }\end{array}$ \\
\hline Control specimens & $51.98(6.48) \mathrm{A}$ & $42.76(10.05) \mathrm{A}$ \\
\hline $\begin{array}{l}\text { Gamma irradiated unmodified control } \\
\text { specimens }\end{array}$ & $50.47(11.53) \mathrm{A}$ & $49.01(7.00) \mathrm{A}$ \\
\hline $\begin{array}{l}\text { Modified and gamma } \text { irradiated wood } \\
\text { specimens - MIX A }(48 \% \text { styrene + } 52 \% \text { UP } \\
\text { resin T1) }\end{array}$ & $19.09(7.10) \mathrm{B}$ & $9.24(1.58) \mathrm{B}$ \\
\hline $\begin{array}{l}\text { Modified and gamma } \text { irradiated wood } \\
\text { specimens - MIX B }(48 \% \text { styrene }+52 \% \text { UP } \\
\text { resin T1 UV) }\end{array}$ & $17.10(5.58) \mathrm{B}$ & $6.98(2.61) \mathrm{B}$ \\
\hline $\begin{array}{l}\text { Modified and gamma irradiated wood } \\
\text { specimens - MIX C (48\% styrene + 52\% UP) }\end{array}$ & $12.14(7.34) \mathrm{BC}$ & $3.46(1.13) \mathrm{C}$ \\
\hline
\end{tabular}

Table 5 illustrates weight losses occurred in the specimens and termite mortalities obtained in termite resistance tests. Generally, the weight losses and termite mortalities were in good accordance. Modifications with styrene and UP resin decreased weight losses in comparison with control and untreated/irradiated specimens. Considering the low termite mortalities and weight losses of around 5\% in modified specimens, styrene and PU-resin system was termite deterrent rather than toxic. Gamma irradiation in control specimens resulted in slightly higher weight losses in comparison with control specimens; however, termite mortalities were also higher in those specimens in comparison with controls. 
Table 5. Termite resistance test results*

\begin{tabular}{lcc}
\hline \multicolumn{1}{c}{ Specimens / Treatments } & $\begin{array}{c}\text { Weight loss (\%) after } \\
\text { termite attack }\end{array}$ & $\begin{array}{c}\text { Termite mortality } \\
(\%)\end{array}$ \\
\hline Control specimens & $17.06(2.71) \mathrm{A}$ & $4.44(1.26) \mathrm{D}$ \\
\hline Gamma irradiated unmodified control specimens & $17.66(1.57) \mathrm{A}$ & $9.49(0.70) \mathrm{C}$ \\
\hline $\begin{array}{l}\text { Modified and gamma irradiated wood specimens - } \\
\text { MIX A (48\% styrene + 52\% UP resin T1) }\end{array}$ & $4.50(1.61) \mathrm{B}$ & $34.34(0.93) \mathrm{A}$ \\
\hline $\begin{array}{l}\text { Modified and gamma irradiated wood specimens - } \\
\text { MIX B (48\% styrene + 52\% UP resin T1 UV) }\end{array}$ & $5.41(1.49) \mathrm{B}$ & $34.14(1.53) \mathrm{A}$ \\
\hline $\begin{array}{l}\text { Modified and gamma irradiated wood specimens - } \\
\text { MIX C (48\% styrene + 52\% UP) }\end{array}$ & $4.98(1.08) \mathrm{B}$ & 21.61 (1.40)B \\
\hline $\begin{array}{l}\text { *Each number is average of 5 specimens. Values in the parentheses are standard deviations. The same letters in each } \\
\text { column indicate that there is no statistical difference between the specimens according to Duncan's Multiply Range Test } \\
\text { (p } \square \leq 0.05) .\end{array}$
\end{tabular}

Katsumata et al. (2007c) have stated that sapwood of Cryptomeria japonica and heartwood of Pseudotsuga menziesii, which are nondurable, have become more vulnerable to termite attack after gamma irradiation; however, the effect of gamma irradiation was not observed for heartwood of Larix kaempferi and Chamaecyparis obtuse with antifeedant substances and durable wood. Katsumata et al. (2007a) previously showed that gamma irradiation improved intake by termites of $C$. japonica; however, it is unclear whether gamma irradiation increased termite feeding in wood species with antitermite substances due to low termite resistance of $C$. japonica wood.

\section{Conclusion}

UP resins are mostly used in presence of other monomers, making them less costly and improving their properties. UP resin and styrene are generally polymerized in wood by gamma radiation. In this study, modifications by styrene and UP resin with different formulations and gamma irradiation greatly improved water absorption and volumetric swell of wood specimens in comparison with unmodified control specimens. Even though such modifications did not inhibit completely mold growth, decay fungi, and termites in the specimens, weight losses is decay resistance tests by $T$. versicolor and $T$. palustris fungi decreased considerably while mold scorings with two formulations of modifying agents were smaller than those occurred in control specimens. Modified specimens resulted in less weight losses in termite resistance tests in comparison with control specimens.

\section{Acknowledgements}

This study is a part of a research project entitled "Conservation of cultural heritage by radiation technology" supported by Turkish Atomic Energy Authority, Turkey. Part of this study was presented at ORENKO2018 International Forest Products Congress, Trabzon, Turkey, 26-29 September 2018.

\section{References}

ASTM D 4445-10 (2012). Standard Test Method for Fungicides for Controlling Sapstain and Mold on Unseasoned Lumber (Laboratory Method), Destination D4445-10, Virginia Polytechnic Institute pursuant to License Agreement.

Aziz, S. H., Ansell, M. P., Clarke, S. J., \& Panteny, S. R. (2005). Modified Polyester Resins for Natural Fibre Composites. Composites Science and Technology, 65, 525535.

Baki, H., Yalcin, O. \& Hakki, A. (1993). Improvement of Wood Properties by Impregnation with Macromonomeric Initiators. Journal of Applied Polymer Science, 47, 1097.

Borysiak, S. A. (2010). Study of Transcrystallinity in Polypropylene in The Presence of Wood Irradiated with Gamma Rays. Journal of 
Thermal Analysis and Calorimetry, 101, 43945.

Cao, X. \& Lee, L. J. (2003). Control of Shrinkage and Residual Styrene of Unsaturated Polyester Resins Cured at Low Temperatures: I. Effect of Curing Agents. Polymer, 44, 1893-1902.

Chawla, J. S. (1985). Degradation of LignoCellulose Biomass. Holzforschung und Holzverwertung, 37(2), 101-105.

Despot, R, Hasan, M, Rapp, A. O, Brischke, C, Humar, M, Welzbacher, C.R and Ražem, D. (2012). Changes in Selected Properties of Wood Caused by Gamma Radiation. Gamma Radiation, F. Adrovic, Ed., Intech, 281-304.

Devi, R. R., Ali, I. and Maji, T. K. (2003). Chemical Modification of Rubber Wood with Styrene in Combination with a Crosslinker: Effect on Dimensional Stability and Strength Property. Bioresource Technology, 88, 185188

Dholakiya, B. (2012). Unsaturated Polyester Resin for Specialty Applications. in "Polyester," Hosam El-Din M. Saleh, Ed., Intech Open, 167-202.

EN (1997a) EN 113: Wood Preservatives-Test Method for Determining the Protective Effectiveness Against Wood Destroying Basidiomycetes-Determination of the Toxic Values. No: 1-2, European Committee for Standardization, Central Secretariat: rue de Stassart 36, B-1050 Brussels.

EN (1997b) EN 84: Wood Preservatives, Accelerated Ageing of Treated Wood Prior to Biological Testing. Leaching Procedure. European Committee for Standardization, Central Secretariat: rue de Stassart 36, B-1050 Brussels.

Hill, C. A. S. (2006). Wood Modification Chemical, Thermal and Other Processes. Wiley Series in Renewable Resources, Wiley and Sons, Chichester, UK, 260.

Ibach, R. and Rowell, R.M. (2013). Lumen modifications. In "Wood Chemistry and Wood Composites," Second Edition, R.M. Rowell, Ed., CRC Press Taylor and Francis Group, New York, 599-626.

Japanese Standards Association (JIS K) (2004) Japan Industrial Standard (JIS) K 1571. Test methods for determining the effectiveness of wood preservatives and their performance requirements. Japanese Standards Association, Tokyo.

Jurkin, T. and Pucic, I. (2006). Post-Irradiation Crosslinking of Partially Cured Unsaturated
Polyester Resin. Radiation Physics and Chemistry, 75, 1060-1068.

Katsumata, N., Yoshimura, T., Tsunoda, K., \& Imamura, Y. (2007a). Resistance of GammaIrradiated Sapwood of Cryptomeria Japonica to Biological Attacks. Journal of Wood Science, 4, 320-323.

Katsumata, N., Tsunoda, K., Toyoumi, A., Yoshimura, T., \& Imamura, Y. (2007b). Comparative termite (Isoptera: Rhinotermitidae) Feeding Preference Among Gamma-Irradiated and Unirradiated Wood. Sociobiology, 1, 155-162.

Katsumata, N., Yoshimura, T., Tsunoda, K., \& Imamura, Y. (2007c). Termite feeding preference to four wood species after gamma irradiation. J Wood Sci, 53, 361-364.

Mahmoud, A. A., Eissa, A. M. F., Omar, M. S., El-Sawy, A. A. \& Shaaban, A. F. (2001). Improvements of White Pine Wood Properties by Impregnation with Unsaturated Polyesters in Admixture with Styrene. $J$ of Applied Polymer Science, 82, 1410-1416.

Rowell, R. M., Ibach, R. E., McSweeny, J., \& Nilsson, T. (2009). Understanding Decay Resistance, Dimensional Stability and Strength Changes in Heat Treated and Acetylated Wood. Wood Material Science and Engineering, 4(1-2), 14-22.

Rowell, R. M. (2016). Dimensional Stability and Fungal Durability of Acetylated Wood. Drewno, 59(197), 139-150.

Sandberg, D., Kutnar, A. \& Mantanis, G. (2017). Wood Modification - A Review. iForest, 10: 895-908.

Seifert, K. (1964). Zur Chemie gammabestrahlten Holzes. Holz als Roh- und Werkstoff, 22(7), 267-275.

Unger, A., Schniewind, A. P., \& Unger, W. (2001). Conservation of Wood Artifacts: A Handbook. Springer Science \& Business Media, Springer- Verlag Berlin Heidelberg, 578. 